\title{
Different intervals of behavioral observation in the scanning method and the real behavior of pigs
}

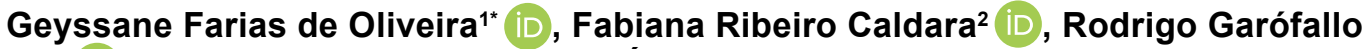 \\ Garcia² $^{\text {iD }}$, Leonardo de Oliveira Seno², Ádila Vasconcelos Marcon², Luciana Foppa ${ }^{3}$ (iD, \\ Renata Aparecida Martins², Carla Crone ${ }^{2}$
}

\footnotetext{
${ }^{1}$ Universidade Estadual Paulista, Faculdade de Medicina Veterinária e Zootecnia, Botucatu, SP, Brasil.

${ }^{2}$ Universidade Federal da Grande Dourados, Faculdade de Ciências Agrárias, Dourados, MS, Brasil.

${ }^{3}$ Universidade Estadual de Londrina, Programa de Pós-graduação em Ciência Animal, Londrina, PR, Brasil.
}

\begin{abstract}
The objective of this work was to study the behavior of swine females in the grower phase using different observation intervals (continuous, 5, and $10 \mathrm{~min}$ ). A total of 42 swine were used, 14 of them for each treatment, which were identified with a marker stick. These animals were observed using the focal sampling method for $5 \mathrm{~h}$. The treatments were the observation intervals: continuous, every $5 \mathrm{~min}$, and every $10 \mathrm{~min}$. Among the behaviors analyzed during the experiment, the different observation intervals did not affect the estimated time spent in the activities. Time observation intervals of 10 min or less adequately describe the duration of the main behavioral parameters of female pigs in this setting.
\end{abstract}

Key Words: ethology, pig production, social behavior

\section{Introduction}

Behavior is the reaction of an organism through which it interacts with the environment. Behaviors may indicate animal welfare, particularly in a confinement environment. Behavioral assessment has the advantage of being a noninvasive (Düpjan et al., 2008), quick, and practical technique (Poletto, 2010) that measures the status of an individual in relation to the environment (Broom, 1991).

Behavioral observations are used to quantify biological responses and must be validated and selected according to the specific goals of each study. Among the methodologies most commonly employed in research on pigs are scan and focal animal sampling (Altmann, 1974). Scan sampling consists of recording the behaviors of all individuals sighted during pre-established sampling periods spaced with fixed intervals (Altmann, 1974; Cullen Jr and ValladaresPadua, 1997). Among the advantages of this method is the possibility of recording different behaviors performed simultaneously by different individuals.

Received: January 29, 2018

Accepted: April 16, 2018

*Corresponding author: geyssanesousa@hotmail.com

Copyright (C) 2018 Sociedade Brasileira de Zootecnia. This is an Open Access article distributed under the terms of the Creative Commons Attribution License (http://creativecommons.org/licenses/by/4.0/), which permits unrestricted use, distribution, and reproduction in any medium, provided the original work is properly cited.
Focal animal sampling requires the observation of a single individual of the group for a pre-determined sampling period and recording all the performed activities (Altmann, 1974). Data collection may be continuous, in which the duration of each behavior is recorded, or instantaneous, in which the sampling period is split into subperiods of seconds or minutes during which the behavior is recorded (Cullen Jr and Valladares-Padua, 1997).

Instantaneous sampling is faster and facilitates some types of assessments. Among the advantages of this method, besides the greater randomness, is the possibility of recording less frequent behaviors (or those performed when the individuals are alone, far from their group) and the ability to analyze data by frequency (percentage) or by duration (in hours or minutes) (Setz, 1991). Any understanding of the activities that comprise animal behavior depends on the methodology used in each assessment (Oliveira et al., 2011). Any method used must obtain reliable data minutes (Marques et al., 2008). Observations over a long period, while providing complete information, are often not possible for practical reasons.

In instantaneous sampling, the individuals are observed during pre-established sampling periods and the frequency of each behavior is presented as a percentage of the total observations. In an effort to transform this frequency (\%) into duration, it is important to know the distribution of behaviors. Does instantaneous assessment reflect the actual 
behavior of pigs over time? If so, what pre-established interval of time provides the best estimate?

This study compared the results of behavioral assessments of pigs in the grower phase employing both continuous and instantaneous sampling methods, the latter using different pre-established intervals (5 and $10 \mathrm{~min}$ ).

\section{Material and Methods}

This research was conducted according to the institutional committee on animal use (case no. 06/2015). The experiment was carried out in September 2015 in a commercial pig farm in the city of Dourados, MS, Brazil $\left(22^{\circ} 13^{\prime} 18.54^{\prime \prime} \mathrm{S}, 54^{\circ} 48^{\prime} 23.09^{\prime \prime} \mathrm{W}\right.$, and mean altitude of $430 \mathrm{~m})$. The climate in the region, according to the Köppen classification, is humid mesothermal (Cwa) with wet summers and dry winters, featuring mean annual rainfall of $1,500 \mathrm{~mm}$ and mean annual temperature of $22{ }^{\circ} \mathrm{C}$. The animals were housed in a masonry barn $(100.0 \times$ $8.0 \mathrm{~m}$ ) containing collective pens with $84.0 \mathrm{~m}^{2}$ of total area equipped with a water pond, automated feeding troughs, and nipple drinking troughs.

The experimental pen featured environmental enrichment objects made of PVC pipes of $25 \mathrm{~cm}$ in length and $200 \mathrm{~mm}$ in diameter connected to four non-toxic plastic hoses with a length of $65 \mathrm{~cm}$, which allowed pigs to exhibit the chewing exploratory activity. Two objects were placed in the pen at the height of the eyes of pigs to facilitate eye contact. The experiment used 14 female pigs of the same commercial strain, randomly selected, with a mean initial weight of $25 \pm 2 \mathrm{~kg}$. The animals were marked with a marking rod with different symbols on the side and back, through which they were identified.

The assessments were performed using images obtained through video cameras placed at the upper part of the pen and directly connected to a device equipped with a video capture card and LCD monitor. The images were recorded from 9:00 to 14:00 $\mathrm{h}$ for a total of $5 \mathrm{~h}$ of continuous recording per day during the three-day experimental period. After the images were recorded, they were stored in the memory of the monitoring device and later used for the assessments. A behavioral ethogram was constructed to perform the evaluations based on the adaptation of the proposed methodology (Campos et al., 2010; Pandorfi et al., 2006) (Table 1). To create the frequency histogram of the behavioral activities, the images were visualized using the video software CyberLink. The film footage was analyzed either continuously, or in 5- and 10-min intervals. The identity of each animal and its activities were recorded. The behavior of the pig was analyzed individually, and each animal was considered an experimental unit.

The mean values for each behavior in the ethogram were reported in minutes and as percentages of the total time. At each observation day, 60 events were recorded at 5-min intervals and 30 events at 10-min intervals. For each event, we considered that the pig exhibited this specific behavior until the next event (5 or $10 \mathrm{~min}$ ) (Machado et al., 2017).

The duration of each displayed behavior in minutes was calculated based on the average of 14 animals per treatment. The frequency was considered as a percentage of the total experimental time. The values presented were the average number of a given behavior over three days.

The data deviated from normal distribution of nonparametric Kruskal-Wallis tests were used for the analysis. An a priori probability level was set at 5\%. All analyses were performed by the statistical software $\mathrm{R}$ version 2.5.1 (R Development Core Team, 2011).

\section{Results}

The estimated duration (minutes or \%) of the behaviors were not affected by observation interval $(\mathrm{P}>0.05)$ confounding (Figure 1).

When the frequency data were transformed into minutes, no significant differences were found between the continuous and instantaneous scan sampling methods using intervals of 5 or $10 \mathrm{~min}$, for our behaviors of interest $(\mathrm{P}>0.05)$.

Nonetheless, when the 10-min observation interval was used, sexual behavior was not observed, which could lead to the conclusion that it did not occur at any time. However,

Table 1 - Ethogram used to assess behavioral parameters of pigs in the growing phase

\begin{tabular}{ll}
\hline Behavior & Dniffing, biting, or nuzzling the enrichment object. \\
\hline Interacting with an object & Confrontation, headbutts, fights with a partner, and chasing. \\
Agonistic behavior & Exploratory function, investigating, watching, and sniffing the environment and compounds of the pen. \\
Nuzzling and exploring & Pig with the head in the feeding trough. \\
Eating & Pig with the head in the drinking trough. \\
Drinking & Animal lying with the body in contact with the floor or flat against it, with eyes shut or open. \\
Lying & Mounting a partner. \\
Sexual behavior & Sitting or walking slowly in the pen. \\
Sitting and walking &
\end{tabular}




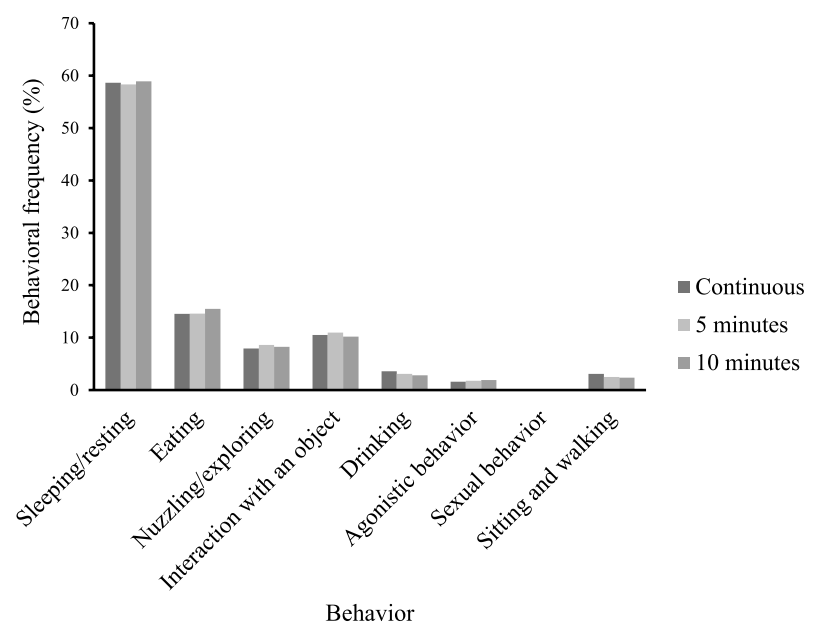

Figure 1 - Behavioral frequency (\%) of pigs in the grower phase, recorded by different observation intervals (continuous, 5 , or $10 \mathrm{~min}$ ).

using continuous observation or scan sampling with 5-min interval, this behavior was recorded for some animals, although at a low frequency.

\section{Discussion}

We hypothesized that if different time intervals were used in behavioral sampling, this would result in different behavioral frequencies for the focal behaviors from those measured during continuous observation.

Massari et al. (2015) employed the focal animal methodology previously proposed by Altmann (1974) with 15 min of observation and 3-min intervals to assess typical behaviors (standing, lying, and eating) and continuous observation for dynamic behaviors (social interaction and agonistic, exploratory, and stereotypic behaviors) to compare the behavior of pigs in the grower and finisher phases using the "wean to finish" system. That methodology suggests that intervals and observation period must be determined according to the characteristics of each behavior.

Bowden et al. (2008) observed the behavior of pigs over $4 \mathrm{~h}$ with intervals of $1,2,3,5,10,15,30$, and $60 \mathrm{~min}$ and found a difference in the activity of drinking water for intervals above $5 \mathrm{~min}$, but no significant differences for the behavior sitting, walking, standing, and inactive behaviors. Jacobsen and Wiggins (1982) stated that intervals between observations above 20 min could lead to poor data estimates for the overall observation period of captive animals. Research on bovine behavior concluded that the main behavior patterns such as grazing, ruminating, and idling can be observed with reasonable precision in intervals of up to $30 \mathrm{~min}$; however, the number of animals must be larger (Hull et al., 1960).

Finally, Silva et al. (2008), in their study with dairy cows, suggested that choosing the appropriate interval to estimate the duration of each behavior may depend on the type of variable to be analyzed. According to the authors, longer intervals between observations (up to $30 \mathrm{~min}$ ) can be used to study the total daily times of activities such as feeding, rumination, and leisure. However, they recommend a maximum interval of $10 \mathrm{~min}$ when the objective of the study is the discrete series of activities mentioned above.

It should be noted, however, that these are ongoing and sustained activities for extended periods of time. In specific species with complex and varied behavioral repertoires such as pigs, in which activities are performed in a short time, long intervals of observation may mask behaviors that occur sporadically and for very short periods, such as agonistic and sexual behaviors, belly nosing, etc.

\section{Conclusions}

Behavioral assessments with time intervals of up to 10 min adequately reflect the behavioral repertoire in female pigs for the ethogram we chose, in the environment we measured them. For specific, short-term behaviors, continuous assessment or scan sampling with shorter intervals of time are recommended for growing pigs.

\section{References}

Altmann, J. 1974. Observational study of behavior: sampling methods. Behaviour 49:227-267.

Bowden, J.; Karriker, L. and Stalder, K. 2008. Scan sampling techniques for behavioral validation in nursery pigs. Iowa State University Animal Industry Report.

Broom, D. 1991. Animal welfare: concepts and measurement Journal of Animal Science 69:4167-4175. https://doi.org/10.2527/ 1991.69104167x

Campos, J. A.; Tinôco, I. F. F.; Silva, F. F.; Pupa, J. M. R. and Silva, I. J. O. 2010. Enriquecimento ambiental para leitões na fase de creche advindos de desmame aos 21 e 28 dias. Revista Brasileira de Ciências Agrárias 5:272-278. https://doi.org/10.5039/agraria. v5i2a660

Cullen Jr, L. and Valladares-Padua, C. 1997. Métodos para estudos de ecologia, manejo e conservação de primatas na natureza. p.239-269. In: Manejo e conservação de vida silvestre no Brasil. Valladares-Padua, C.; Bodmer, R. E.; Cullen Jr, L., org. MCT/CNPQ, Brasília; Sociedade Civil Mamirauá, Belém.

Düpjan, S.; Schön, P.; Puppe, B.; Tuchscherer, A. and Manteuffel, G. 2008. Differential vocal responses to physical and mental stressors in domestic pigs (Sus scrofa). Applied Animal Behaviour Science 114:105-115. https://doi.org/10.1016/j.applanim.2007.12.005

Hull, J.; Lofgreen, G. and Meyer, J. 1960. Continuous versus intermittent observations in behavior studies with grazing cattle. Journal of Animal Science 19:1204-1207. 
Jacobsen, N. and Wiggins, A. 1982. Temporal and procedural influences on activity estimated by time-sampling. The Journal of Wildlife Management 46:313-324.

Machado, S. P.; Caldara, F. R.; Foppa, L; Moura, R.; Gonçalves, L. M. P.; Garcia, R. G.; Nääs, I. A.; Nieto, V. M. O. S and Oliveira, G. F. 2017. Behavior of pigs reared in enriched environment: alternatives to extend pigs attention. Plos One 12:e0168427. https://doi.org/10.1371/journal.pone.0168427

Massari, J. M.; Curi, T. M. R. C.; Moura, D. J.; Medeiros, B. B. L. and Salgado, D. D. 2015. Características comportamentais de suínos em crescimento e terminação em sistema "wean to finish". Engenharia Agrícola 35:646-656. https://doi.org/10.1590/18094430-Eng.Agric.v35n4p646-656/2015

Marques, J. A.; Pinto, A. P.; Abrahão, J. J. S. and Nascimento, W. G. 2008. Intervalo de tempo entre observações para avaliação do comportamento ingestivo de tourinhos em confinamento. Semina: Ciências Agrárias 29:955-960. https://doi.org/10.5433/ 1679-0359.2008v29n4p955

Oliveira, P. A.; Marques, J. A.; Barbosa, L. P.; Oliveira, G. J. C.; Pedreira, T. M. and Silva, L. L. 2011. Aspectos metodológicos do comportamento ingestivo de vacas lactantes em pastejo de "Brachiaria decumbens". Revista Brasileira de Saúde e Produção Animal 12:166-175.

Pandorfi, H.; Silva, J. I. O.; Carvalho, J. L. and Piedade, S. M. 2006. Estudo do comportamento cioclimático de matrizes suínas alojadas em baias individuais e coletivas, com ênfase no bem-estar animal na fase de gestação. Engenharia Rural 17:1-10.

Poletto, R. 2010. Bem-estar animal. Suíno.com, Tangará, 5 abr. 2010. Série especial bem-estar animal. Available at: $<$ http://www.suino. com.br/SanidadeNoticia.aspx? codigoNot $=\mathrm{zSoHh} 5 \mathrm{f} 8 \mathrm{w} 90=\&$ title $=$ SERIE+ESPECIAL:+BEM>. Accessed on: Aug. 21, 2016.

Setz, E. Z. F. 1991. Métodos de quantificação de comportamentos de primatas em estudos de campo. p.411-435. In: A primatologia no Brasil. Rylands, A. B. and Bernardes, A. T., eds. vol. 3. Fundação Biodiversitas, Belo Horizonte.

Silva, R. R.; Prado, I. N.; Carvalho, G. G. P.; Santana Junior, H. A.; Silva, F. F. and Dias, D. L. S. 2008. Efeito da utilização de três intervalos de observações sobre a precisão dos resultados obtidos no estudo do comportamento ingestivo de vacas leiteiras em pastejo. Ciência Animal Brasileira 9:319-326. 